\title{
ŠUOLIUKŲ PRIEŠKRŪVIO POVEIKIS MERGINŲ DEGUONIES SUVARTOJIMO KAITAI BËGANT VIDUTINIU IR DIDELIU GREIČIU
}

\author{
Kristina Zaičenkovienė, Arvydas Stasiulis \\ Lietuvos kūno kultūros akademija, Kaunas, Lietuva
}

\begin{abstract}
Kristina Zaičenkovienė. Biologijos mokslų magistrè. Lietuvos kūno kultūros akademijos biomedicinos mokslų krypties doktorantė, Kūno kultūros ir gimnastikos katedros lektorè. Moksliniu tyrimų kryptis - aerobinio ir anaerobinio pajègumo, bioenergetikos greitoji ir lètoji adaptacija
\end{abstract}

\section{SANTRAUKA}

Tyrimo tikslas — nustatyti 100 vertikaliu didžiausiu pastangu šuoliuku, atliekamu tiesiomis kojomis nušokus nuo $47 \mathrm{~cm}$ pakylos, poveiki deguonies suvartojimo kaitai bègant vidutiniu ir dideliu aerobiniu greičiu. Büti tiriamos sutiko 9 fiziškai aktyvios merginos, kuri乇 amžius, ügis, svoris, maksimalusis deguonies suvartojimas atitinkamai buvo 22,8 (4,1) m., 1,65 (0,48) m, 58,1 (4,7) $\mathrm{kg}$ ir 42,4 (6,0) $\mathrm{ml} / \mathrm{kg} / \mathrm{min}$. Tiriamosios buvo testuojamos keturis kartus bègimo takeliu. Visu tyrimu metu registruoti tiriamuju kvépavimo duju apykaitos, ŠSD, subjektyviai suvokiamu pastangu, kraujo laktato koncentracijos rodikliai. Pradžioje norint nustatyti maksimaluji deguonies suvartojima ir ventiliacinius slenksčius, pagal kuriuos skaičiuotas pastoviu krūviu (PK) intensyvumas, tiriamosios atliko nuosekliai didinama krūvi. Per kitus tris kartus buvo atliekami PK: po vienq vidutinio $(90 \%$ pirmojo VS (ventiliacinio slenksčio) ir didelio (pirmasis VS $+75 \%$ skirtumo tarp VS 2 ir VS 1) intensyvumo. Praejus kelioms dienoms po kontroliniu PK, tiriamoji atlikdavo prieškrūvi (100 šuoliuku po nušokimu nuo $47 \mathrm{~cm}$ aukščio pakylos kas 20 s.). Praejus vienai ir 24 valandoms po prieškrūvio buvo atliekami tie patys $P K$.

Tiriamosios jautè vidutiniška blauzdos raumenu skausma praejjus 24 valandas po prieškrūvio $(3,7(1,2)$ balo). Tik atliekant vidutinio intensyvumo $\mathrm{PK}$ kai kurie $\mathrm{VO}_{2}$ rodikliai pakito reikšmingai: praejus vienai valandai po prieškrūvio greitosios kaitos fazès amplitudè ir vidutinès $\mathrm{VO}_{2}$ reikšmès 4, 5 ir 6 krüvio minutę padidèjo. Praejjus 24 valandoms po prieškrūvio, taip pat abiem atvejais atliekant didelio intensyvumo $P K$, statistišskai reikšmingu šiu rodikliu pokyčiu nebuvo. Be to, praèjus 24 valandoms po prieškrūvio padidèjo SSP (subjektyviai suvokiamos pastangos) 3 ir 6 vidutinio intensyvumo PK minute.

Apibendrinant galima teigti, kad ekscentrinis-koncentrinis blauzdos raumenu prieškrūvis (100 šuoliuku, atliekamu tiesiomis kojomis po nušokimo nuo $47 \mathrm{~cm}$ pakylos) praejjus vienai valandai po jo padidina deguonies suvartojima pastovios būklès fazèje bègant vidutiniu greičiu. Neturi reikšmingo poveikio ir šio rodiklio dydžiui praejjus 24 valandoms po prieškrūvio, taip pat deguonies suvartojimo dydžiui ir jo kaitos greičiui bègant dideliu greičiu bei šio rodiklio kaitos greičiui bègant vidutiniu ir dideliu greičiu praejjus vienai ir 24 valandoms po prieškrūvio.

Raktažodžiai: deguonies suvartojimas, subjektyviai suvokiamos pastangos, prieškrūvis, pastovus krūvis, bègimas.

\section{IVADAS}

$\mathrm{P}$ o neiprastos fizinès veiklos, kurią sudaro ekscentriniai ar ekscentriniai-koncentriniai raumenu susitraukimai, gali pasireikšt vèluojantis raumenų skausmas (VRS), kuris labiausiai juntamas praèjus $24-72$ valandoms po krūvio (Armstrong, 1984). VRS gali būti susijęs su jungiamojo audinio ir miofibrilių pažeida (Davies, White, 1981; Friden et al., 1983), viduląsteliniu pabrinkimu ir padidejusiu spaudimu raumens vi- duje (Friden et al., 1986; 1988), pablogèjusia mikrocirkuliacija ir raumenu jègos sumažejjimu (Davies, White, 1981; Sargeant, Dolan, 1989). Po 100 vertikaliu šuoliu nuo pakylos raumenu funkcija išlieka pablogejusi bent jau 24 valandas po krūvio (Skurvydas et al., 2000). Sukaupta daug duomenų, kaip skirtingo intensyvumo ar pobūdžio prieškrūvis veikia deguonies suvartojimo dydi ir kaitą îvairių fizinių krūvių metu (Tordi et al., 2003; 
Endo et al., 2004; Sanchis Moysi et al., 2005). Duomenys apie VRS sukeliančių ekscentriniu krūviu poveiki deguonies suvartojimui pastovaus intensyvumo krūvių metu negausūs ir jų rezultatai prieštaringi. Nustatyta, kad praejjus dviems paroms po VRS sukeliančių krūvių deguonies suvartojimas ar jo kaitos greitis antroje ir trečioje fazeje nepakinta atliekant didelio intensyvumo aerobinị krūvị veloergometru (Sanchis Moysi et al., 2005; Schneider et al., 2007). Po ekscentrinių fizinių pratimų, sukèlusių raumenų pažeidą, bėgimo ekonomiškumas po vienos-keturių parų liko nepakitęs (Paschalis et al., 2005; Vassilis et al., 2008), o praejjus vienai valandai po ekscentrinio-koncentrinio šuoliu prieškrūvio deguonies suvartojimas vidutinio ir didelio intensyvumo veloergometriniu krūvių metu padidejo (Ratkevičius et al., 2006). $\mathrm{VO}_{2}$ bėgant vidutiniu greičiu ir lètasis $\mathrm{VO}_{2}$ komponentas bègant dideliu greičiu padidejo praejjus vienai valandai po intervalinès bėgimo treniruotès (James, Doust, 1998; 1999). $\mathrm{VO}_{2}$ kinetinès ypatybės bėgant dideliu greičiu nepakito praejus 4 minutėms po analogiško to paties intensyvumo prieškrūvio (Jones et al., 2008), o bėgimo ekonomiškumas pablogejjo po 60 minučiu bègimo dideliu intensyvumu (Sproule, 1998) ar 30 minučių bėgimo nuokalne (Chen et al., 2007). Nèra duomenu apie ekscentriniu prieškrūvių poveiki $\mathrm{VO}_{2}$ kaitai skirtingo intensyvumo bėgimo krūvio pradžioje ir įvairiais atsigavimo etapais po tokio prieškrūvio.

Taigi tyrimo tikslas - ištirti deguonies suvartojimo kaitą po bejgimo vidutiniu ir dideliu greičiu praejus vienai ir 24 valandoms po ekscentriniokoncentrinio blauzdos raumenu prieškrūvio (100 šuoliukų po nušokus nuo pakylos).

\section{TYRIMO METODIKA}

Tiriamieji. Būti tiriamos sutiko devynios fiziškai aktyvios Lietuvos kūno kultūros akademijos studentès (1 lent.). Kiekviena tiriamoji buvo testuota keturis kartus tokiomis pačiomis sąlygomis.
Testavimo išvakarèse buvo prašoma, kad tiriamosios neatliktų sunkaus fizinio krūvio, o testavimo dieną būtų visiškai nesimankštinusios ir pavalgiusios mažiausiai prieš dvi valandas iki tyrimo. Skirtingu testavimu atlikimo laikas buvo derinamas ir prašoma, kad tiriamosios visada atvyktų tuo pačiu paros metu (dažniausiai ryte).

Tyrimo metodai. Antropometrija. Naudojant specialų ūgio matuoklị ir kūno kompozicijos analizatoriu „TBF-300“ (Japonija) buvo nustatytas tiriamujų ūgis ir kūno svoris.

Spirometrija. Norint nustatyti tiriamujų dujų apykaitos rodiklius, nešiojamu dujų analizatoriu „Oxycon Mobile“ (Vokietija) buvo registruojami kiekvieno tiriamosios kvėpavimo ciklo rodikliai: deguonies suvartojimas $\left(\dot{\mathrm{V}}_{2}\right)$, anglies dioksido išskyrimo greitis $\left(\dot{\mathrm{V}} \mathrm{CO}_{2}\right)$, plaučiu ventiliacija $\left(\dot{\mathrm{V}}_{\mathrm{E}}\right)$, kvėpavimo koeficientas (RER), $\mathrm{O}_{2}$ ir $\mathrm{CO}_{2}$ slègis ore iškvèpimo pabaigoje $\left(\mathrm{P}_{\mathrm{ET}} \mathrm{O}_{2}\right.$ ir $\left.\mathrm{P}_{\mathrm{ET}} \mathrm{CO}_{2}\right)$. Užregistruotų rodiklių vidutinės reikšmès kas 5 sekundes toliau buvo analizuojamos Microsoft Excel programa.

Pulsometrija. Viso tyrimo metu širdies susitraukimų dažnis (ŠSD) 5 sekundžių intervalais buvo registruojamas pulso matuokliu „Polar S810“ (Suomija) ir toliau analizuojamas Microsoft Excel programą.

Ergometrija. Nuosekliai didinamo krūvio testas (NDK). NDK buvo atliekamas bègtakiu (LE $200 \mathrm{CE}$, HP Cosmos). Tris pirmas minutes bejgimo greitis buvo $7 \mathrm{~km} / \mathrm{h}$, nuo ketvirtos bègimo minutès jis buvo didinamas kas $6 \mathrm{~s}$ po $0,1 \mathrm{~km} / \mathrm{h}$. Krūvis nutraukiamas tada, kai tiriamoji dèl nuovargio nebegalèdavo tęsti bègimo reikiamu greičiu.

Pastovaus intensyvumo krūviai. Vidutinio $(80 \% \mathrm{VeS} 1)$ ir didelio intensyvumo (VeS $1+$ (VeS 2-VeS 1) / 2) krūviai buvo atliekami bègtakiu. Atlikdamos PK tiriamosios 3 minutes $7 \mathrm{~km} / \mathrm{h}$ greičiu bėgdavo, tada 1 minutę stovédavo ant bėgtakio korpuso, kad įsibėgètu bėgtakio takelis iki reikiamo greičio. Paskui 6 minutes atlikdavo individualų vidutinio intensyvumo krūvit, tada

\begin{tabular}{|l|c|}
\hline Amžius, m. & $22,8(4,1)$ \\
\hline Ūgis, $\mathrm{m}$ & $1,65(0,48)$ \\
\hline Svoris, $\mathrm{kg}$ & $58,1(4,7)$ \\
\hline $\mathrm{VO}_{2}$ max, $1 /$ min & $2,474(0,398)$ \\
\hline ŠSD max, tv. / min & $191,6(13,4)$ \\
\hline
\end{tabular}


gulėdamos ilsèdavosi 5 minutes. Po 10 minučiu panašiai buvo atliekamas didelio intensyvumo krūvis. Viso PK metu buvo registruojami vegetaciniu sistemų funkcijos rodikliai.

Deguonies suvartojimo kaitos analize. Norint ivertinti $\mathrm{VO}_{2}$ kaitą darbo metu Microcal Origin programa duomenys buvo analizuojami taikant monoeksponentinę lygti:

$$
\mathrm{VO}_{2}(\mathrm{t})=\mathrm{VO}_{2}(\mathrm{~b})+\mathrm{A} 1\left(1-\mathrm{e}^{-\mathrm{t} / \tau 1}\right)
$$

čia y (b) - $\mathrm{VO}_{2}$ vidutinè pradinè reikšmè per paskutines 30 darbo sekundžių; A - amplitudè, parodanti y reikšmės pokyčio dydi; $\tau$ - laiko konstanta (s) rodo y reikšmès pokyčio greiti; $\mathrm{t}$ - trukmė (s) nuo darbo pradžios.

Norint įvertinti deguonies suvartojimą didelio intensyvumo darbo metu Microcal Origin programa duomenys buvo analizuojama taikant bieksponentinę lygti:

$$
\begin{gathered}
\operatorname{VO}_{2}(t)=\operatorname{VO}_{2}(b) \pm A 1\left(1-e^{-t / \tau 1}\right)+ \\
\text { A } 2\left(1-e^{-t / \tau 2}\right),
\end{gathered}
$$

čia $\mathrm{VO}_{2}$ vidutinè pradinė reikšmė per paskutines 30 darbo sekundžių; A 1 ir A 2 - amplitudès, $\mathrm{VO}_{2}$ - greito ir lèto komponentų pokyčių dydžius; $\mathrm{t}$ - trukmè nuo darbo pradžios (s).

Prieš analizę dẻl kardiodinaminio komponento (Whipp et al., 1982) $\mathrm{VO}_{2}$, pasitelkiant eksponentines lygtis, 20 sekundžiu duomenys nuo kiekvieno darbo pradžios buvo atmetami.

Didelio intensyvumo krūvio metu buvo skaičiuojamas deguonies suvartojimo kaitos lètasis komponentas: skirtumas tarp rodikliu -6 ir 3 darbo minutes.

Kraujo laktato koncentracijos nustatymas. Specialiomis vienkartinèmis priemonèmis buvo imami $0,1 \mathrm{ml}$ kapiliarinio kraujo mèginiai iš rankos piršto, prieš tai odą dezinfekavus. La koncentracija buvo nustatoma „Accutrend Lactate“ analizatoriumi (Vokietija).

Ekscentrinis-koncentrinis prieškrūvis (EKP). Prieš šuoliukus buvo daroma pramankšta - koju raumenu tempimo pratimai. Toliau buvo atliekama 100 vertikalių šuolių didžiausiomis pastangomis. Kiekvienas šuolis buvo atliekamas nušokus nuo $47 \mathrm{~cm}$ pakylos per kelio sąnari tiesiomis kojomis kas $20 \mathrm{~s}$, per kurias tiriamosios neskubèdamos pasirengdavo kitam šuoliui, t. y. užlipdavo ant pakylos.

Tyrimo organizavimas. Testavimai vyko Lietuvos kūno kultūros akademijos Sporto fiziologijos laboratorijoje. Tiriamosios buvo tiriamos keturis kartus. Pirmą kartą atvykus tiriamoji užpildydavo informuoto asmens sutikimo formą ir būdavo supažindinama su tyrimo tikslais, eiga ir organizavimu. Paskui būdavo nustatomi tiriamosios antropometriniai, kūno kompozicijos rodikliai. Tada atliekamas NDK. Prieš NDK tiriamoji atlikdavo 10 minučiu pramankštą. Po jos buvo dedamas nešiojamas dujų analizatorius, pulsometras ir atliekamas NDK. Kiekvienos NDK minutès pabaigoje tiriamujų buvo prašoma i̇vertinti suvokiamas pastangas naudojant 15 lygių Borgo skalę. NDK buvo atliekamas iki visiško nuovargio, t. y. kai tiriamoji negalejjo bėgti bėgimo takelio juostos sukimosi greičiu. Tada tiriamoji 5 minutes ilsèdavosi gulèdama.

Kito tyrimo metu buvo atliekami kontroliniai PK: po vieną vidutinio ir didelio intensyvumo. Po keliu dienu buvo atliekamas EKP ir po vienos, ir po 24 valandu po prieškrūvio tie patys vidutinio ir didelio intensyvumo PK. Po 3 ir 6 PK min buvo prašoma įvertinti suvokiamas pastangas naudojant 15 lygių Borgo skalę. Atlikus PK iš rankos piršto buvo imamas kapiliarinis kraujas ir nustatoma kraujo laktato koncentracija. Visu tyrimu metu duju analizatoriumi „Oxycon Mobile“ (Vokietija) ir pulso matuokliu „Polar S810“ (Suomija) buvo registruojami kvepavimo, dujų apykaitos ir ŠSD rodikliai.

Matematinè statistika. Buvo skaičiuojami analizuojamų rodiklių aritmetiniai vidurkiai ir standartiniai nuokrypiai. Duomenų skirstinio atitikimas normaliajam buvo tikrinamas neparametriniu Kolmogorovo-Smirnovo testu. Deguonies suvartojimo kaita priklausomai nuo testavimo sąlygų buvo analizuojama naudojant vieno veiksnio dispersinę analizę priklausomoms imtims. Statistinių hipotezių patikimumui pasirinkome reikšmingumo lygmeni $\mathrm{p}<0,05$. Duomenis analizavome naudodami kompiuterinès programos LAB Manager, Microsoft Excel, Statistica for Windows.

\section{REZULTATAI}

Tiriamosios jautè vidutinišką blauzdos raumenu skausmą praejjus 24 valandoms po prieškrūvio $(3,7(1,2)$ balo). Po kontrolinio vidutinio ir didelio intensyvumo bėgimo, praejus vienai ir 24 valandoms po prieškrūvio kraujo laktato koncentracija atitinkamai buvo 4,5 $(1,1)$ ir 7,1 $(1,6)$, $4,3(1,7)$ ir $6,5(1,4), 3,8(1,0)$ ir $6,0(1,5) \mathrm{mmol} / 1$ $(p>0,05)$. Subjektyviai suvokiamos pastangos trečią $(p=0,01)$ ir šeštą vidutinio intensyvumo 
1 pav. Deguonies suvartojimo kaita atliekant pastovu vidutinio intensyvumo bėgimo testą
Pastaba. * - statistiškai reikšmingi skirtumai praejus 4 min: $\mathrm{p}=0,012 ; 5 \min : \mathrm{p}=$ 0,$003 ; 6$ min: $\mathrm{p}=0,013$.

2 pav. Deguonies suvartojimo kaita atliekant pastovų didelio intensyvumo bègimo testą
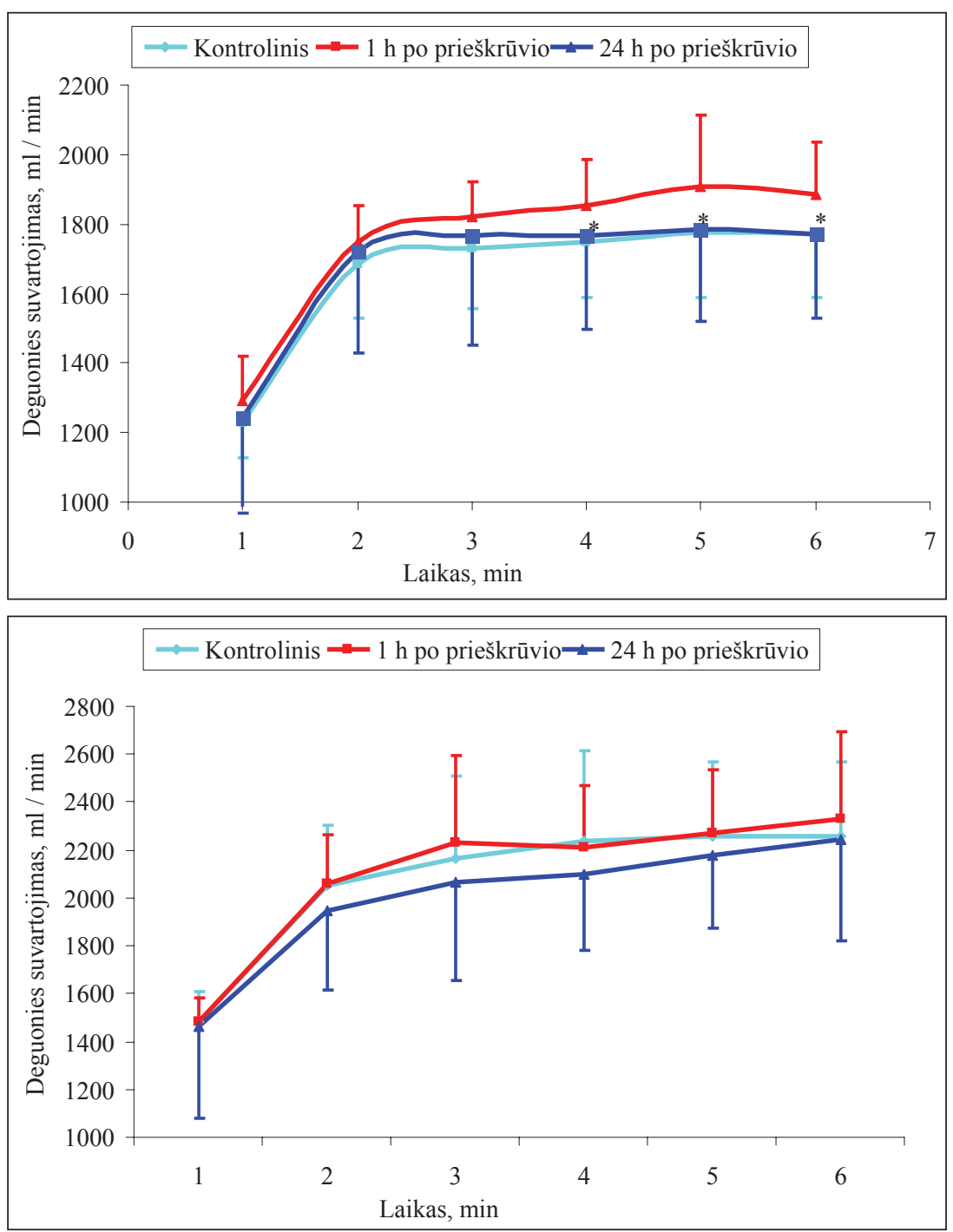

krūvio minutę $(\mathrm{p}=0,03)$ padidejjo statistiškai reikšmingai praejjus 24 valandoms po prieškrūvio, lyginant su kontroliniu bėgimu, o didelio intensyvumo krūvio metu šio rodiklio padidejjimas praejjus vienai valandai po prieškrūvio nesiekè statistiškai reikšmingo lygmens.

Plaučių ventiliacija ir kvėpavimo koeficientas taip pat reikšmingai nekito (2 lent.). Deguonies suvartojimo vidutinès reikšmès kiekvieną krūvio minutę pateiktos 1 ir 2 paveiksle, o jo kaitos rodikliai, apskaičiuoti taikant eksponentinio trendo lygtis (3, 4 lent.). Vidutinis deguonies suvartojimas 4, 5, 6 vidutinio intensyvumo krūvio, atlikto praejjus vienai valandai po prieškrūvio, minutę statistiškai reikšmingai padidejo, lyginant su kontroliniu bėgimu. Greitosios deguonies suvartojimo kaitos fazès amplitudè $(\mathrm{p}=0,013)$ ir vidutinis deguonies suvartojimas šeštą minutę $(p=0,06)$, apskaičiuotas pagal monoeksponentinio trendo lygti šeštos minutès pabaigoje $(p=0,009)$, taip pat padidejo statistiškai reikšmingai praejjus vie- nai valandai po prieškrūvio, lyginant su kontroliniu bègimu.

Greitosios kaitos fazès laiko konstanta vidutinio intensyvumo bėgimo krūvio metu nepakito. Pastebèta deguonies suvartojimo šeštą minutę skirtumo, šio rodiklio vidurkių šeštą ir trečią didelio intensyvumo krūvio minutę ir lètosios kaitos fazès laiko konstantos padidèjimo tendencija praejjus vienai ir 24 valandoms po prieškrūvio, nors skirtumas nèra statistiškai reikšmingas (4 lent.).

\section{REZULTATŲ APTARIMAS}

Šio tyrimo rezultatai parodè, kad 100 šuoliuku, atliekamų tiesiomis kojomis po nušokimo nuo $47 \mathrm{~cm}$ pakylos, prieškrūvis padidina deguonies suvartojimą pastovios būklès fazeje bėgant vidutiniu greičiu praejjus vienai valandai po prieškrūvio, bet neturi reikšmingo poveikio šio rodiklio dydžiui praejjus 24 valandoms po prieškrūvio. 


\begin{tabular}{|c|c|c|c|c|c|c|}
\hline \multicolumn{7}{|c|}{ Vidutinio intensyvumo bẻgimo krūvis } \\
\hline \multicolumn{4}{|c|}{3 minučių bègimas } & \multicolumn{3}{|c|}{6 minučių bėgimas } \\
\hline Rodikliai & Kontrolinis & $\begin{array}{c}1 \mathrm{~h} \text { po } \\
\text { prieškrūvio }\end{array}$ & $\begin{array}{c}24 \text { h po } \\
\text { prieškrūvio }\end{array}$ & Kontrolinis & $\begin{array}{c}1 \mathrm{~h} \text { po } \\
\text { prieškrūvio }\end{array}$ & $\begin{array}{c}24 \text { h po } \\
\text { prieškrūvio }\end{array}$ \\
\hline $\mathrm{VE}, 1 / \min$ & $\begin{array}{l}43,4 \\
(5,1)\end{array}$ & $\begin{array}{l}45,9 \\
(6,8) \\
\end{array}$ & $\begin{array}{c}45,9 \\
(10,5)\end{array}$ & $\begin{array}{l}46,4 \\
(5,6) \\
\end{array}$ & $\begin{array}{l}49,0 \\
(7,5)\end{array}$ & $\begin{array}{c}49,5 \\
(11,3)\end{array}$ \\
\hline RER & $\begin{array}{c}0,91 \\
(0,03) \\
\end{array}$ & $\begin{array}{c}0,85 \\
(0,08) \\
\end{array}$ & $\begin{array}{c}0,86 \\
(0,04)\end{array}$ & $\begin{array}{c}0,94 \\
(0,04)\end{array}$ & $\begin{array}{c}0,86 \\
(0,08) \\
\end{array}$ & $\begin{array}{c}0,90 \\
(0,05)\end{array}$ \\
\hline $\begin{array}{l}\text { ŠSD, } \\
\text { tv. / min }\end{array}$ & $\begin{array}{l}154,9 \\
(9,3)\end{array}$ & $\begin{array}{l}157,8 \\
(13,7)\end{array}$ & $\begin{array}{l}150,1 \\
(15,9)\end{array}$ & $\begin{array}{l}162,0 \\
(9,5)\end{array}$ & $\begin{array}{l}165,1 \\
(12,0)\end{array}$ & $\begin{array}{l}156,6 \# \\
(15,3)\end{array}$ \\
\hline SSP, balai & $\begin{array}{c}9,8 \\
(1,7)\end{array}$ & $\begin{array}{l}10,8 \\
(1,2)\end{array}$ & $\begin{array}{c}11,6^{* * *} \\
(2,0)\end{array}$ & $\begin{array}{l}11,2 \\
(1,3)\end{array}$ & $\begin{array}{l}12,0 \\
(1,4)\end{array}$ & $\begin{array}{l}12,8^{*} \\
(1,8)\end{array}$ \\
\hline \multicolumn{7}{|c|}{ Didelio intensyvumo bėgimo krūvis } \\
\hline $\begin{array}{l}\text { VE, } \\
1 / \min \end{array}$ & $\begin{array}{l}58,2 \\
(7,7)\end{array}$ & $\begin{array}{l}59,8 \\
(8,0)\end{array}$ & $\begin{array}{l}53,7 \\
(9,4)\end{array}$ & $\begin{array}{l}64,6 \\
(9,0) \\
\end{array}$ & $\begin{array}{c}67,5 \\
(10,2)\end{array}$ & $\begin{array}{c}63,7 \\
(11,8)\end{array}$ \\
\hline RER & $\begin{array}{c}0,98 \\
(0,06)\end{array}$ & $\begin{array}{c}0,91 \\
(0,06)\end{array}$ & $\begin{array}{c}0,93 \\
(0,05)\end{array}$ & $\begin{array}{c}0,99 \\
(0,06)\end{array}$ & $\begin{array}{c}0,96 \\
(0,06)\end{array}$ & $\begin{array}{c}0,96 \\
(0,07) \\
\end{array}$ \\
\hline $\begin{array}{l}\text { ŠSD, } \\
\text { tv. / min }\end{array}$ & $\begin{array}{l}175,5 \\
(5,8)\end{array}$ & $\begin{array}{l}175,0 \\
(12,6) \\
\end{array}$ & $\begin{array}{l}172,6 \\
(10,1) \\
\end{array}$ & $\begin{array}{l}182,6 \\
(5,0)\end{array}$ & $\begin{array}{l}183,0 \\
(9,0)\end{array}$ & $\begin{array}{l}181,0 \\
(5,8)\end{array}$ \\
\hline SSP, balai & $\begin{array}{l}13,1 \\
(1,2) \\
\end{array}$ & $\begin{array}{l}13,4 \\
(1,6) \\
\end{array}$ & $\begin{array}{l}14,1 \\
(1,6) \\
\end{array}$ & $\begin{array}{l}14,3 \\
(1,2) \\
\end{array}$ & $\begin{array}{l}15,1 \\
(1,5) \\
\end{array}$ & $\begin{array}{l}15,0 \\
(1,3) \\
\end{array}$ \\
\hline
\end{tabular}

2 lentelè. Plaučių ventiliacijos, kvėpavimo koeficiento, ŠSD ir subjektyviai suvokiamų pastangų (SSP) rodikliai atliekant pastovius vidutinio ir didelio intensyvumo bėgimo krūvius

Pastaba. Statistiškai reikšmingas skirtumas, lyginant su kontroliniu rodikliu $(*-\mathrm{p}<0,05 ; * * \mathrm{p}<0,01)$ ar vienos valandos bėgimu po prieškrūvio (\# - p $<0,05)$.

\begin{tabular}{|l|c|c|c|}
\hline \multicolumn{1}{|c|}{ Rodikliai } & Kontrolinis & 1 h po prieškrūvio & 24 h po prieškrūvio \\
\hline Pradinè reikšmé, 1 / min & $0,385(0,100)$ & $0,388(0,067)$ & $0,336(0,055)$ \\
\hline A 1, 1 / min & $1,354(0,176)$ & $1,442(0,152)^{*}$ & $1,349(0,332)$ \\
\hline T 1, s & $12,3(4,7)$ & $12,7(6,5)$ & $12,9(5,1)$ \\
\hline 3 min, 1 / min & $1,741(0,182)$ & $1,807(0,977)$ & $1,680(0,339)$ \\
\hline 6 min, 1 / min & $1,770(0,179)$ & $1,858(0,150)^{*}$ & $1,708(0,318)$ \\
\hline 6-3 min, 1 / min & $0,029(0,046)$ & $0,052(0,082)$ & $0,029(0,067)$ \\
\hline $\begin{array}{l}\text { Apskaičiuota po 6 min } \\
\text { bėgimo, 1 / min }\end{array}$ & $1,739(0,174)$ & $1,830(0,139)^{* *}$ & $1,685(0,162)$ \\
\hline
\end{tabular}

3 lentelè. Deguonies suvartojimo kaitos rodikliai atliekant pastovų 6 minučių vidutinio intensyvumo bėgimo krūvị (apskaičiuoti taikant monoeksponentinio trendo lygti)

\begin{tabular}{|l|c|c|c|}
\hline \multicolumn{1}{|c|}{ Rodikliai } & Kontrolinis & 1 h po prieškrūvio & 24 h po prieškrūvio \\
\hline Pradine reikšmé, 1 / min & $0,339(0,096)$ & $0,335(0,065)$ & $0,325(0,105)$ \\
\hline A 1, 1 / min & $1,338(0,361)$ & $1,361(0,157)$ & $1,259(0,388)$ \\
\hline T 1, s & $4,7(3,0)$ & $4,8(1,9)$ & $5,9(3,1)$ \\
\hline A 2, 1 / min & $0,618(0,164)$ & $0,674(0,260)$ & $0,661(0,334)$ \\
\hline T 2, s & $89,1(30,6)$ & $110,5(69,7)$ & $159,9(128,5)$ \\
\hline 3 min, 1 / min & $2,189(0,348)$ & $2,190(0,250)$ & $2,058(0,356)$ \\
\hline 6 min, 1/ min & $2,255(0,334)$ & $2,357(0,388)$ & $2,280(0,450)$ \\
\hline 6-3 min, 1 / min & $0,066(0,086)$ & $0,167(0,170)$ & $0,222(0,232)$ \\
\hline $\begin{array}{l}\text { Apskaičiuota po 6 min } \\
\text { bėgimo, 1 / min }\end{array}$ & $2,281(0,335)$ & $2,331(0,306)$ & $2,176(0,231)$ \\
\hline
\end{tabular}

Pastaba. A 1 - greitosios kaitos fazès amplitudè, T 1 - greitosios kaitos fazès laiko konstanta. Statistiškai reikšmingas rodiklio skirtumas, lyginant su kontroliniu: $*-\mathrm{p}<0,05 ; * *-\mathrm{p}<0,01$.

4 lentelè. Deguonies suvartojimo kaitos rodikliai atliekant pastovų 6 minučių didelio intensyvumo bėgimo krūvị (apskaičiuoti taikant bieksponentinio trendo lygti)

Pastaba. A 1 - greitosios kaitos fazès amplitudè, A 2 - lètosios kaitos fazès amplitudè, T 1 - greitosios kaitos fazès laiko konstanta, T 2 - lètosios kaitos fazès laiko konstanta.

Minètas prieškrūvis neturi reikšmingo poveikio deguonies suvartojimo dydžiui ir jo kaitos greičiui bègant dideliu greičiu, taip pat šio rodiklio kaitos greičiui vidutinio ir didelio intensyvumo bègimo metu testuojant praejus vienai ir 24 valandoms po prieškrūvio.
Nėra duomenų, kaip ekscentriniai prieškrūviai veikia $\mathrm{VO}_{2}$ kaitą skirtingo intensyvumo bègimo krūvio pradžioje ir įvairiais atsigavimo po tokio prieškrūvio etapais. Atliekant krūvius veloergometru nustatyta, kad praejus dviems paroms po VRS sukeliančių krūvių deguonies suvartojimas ar jo 
kaitos greitis antroje ir trečioje fazèse nepakinta atliekant didelio intensyvumo aerobinį krūvị veloergometru (Sanchis Moysi et al., 2005; Schneider et al., 2007). Mūsų tyrimo metu taip pat neužfiksuota $\mathrm{VO}_{2}$ kaitos pokyčiu praejjus vienai ir 24 valandoms po ekscentrinio-koncentrinio blauzdos raumenu prieškrūvio. Kita vertus, praejjus vienai valandai po ekscentrinio-koncentrinio šuoliu prieškrūvio deguonies suvartojimas vidutinio ir didelio intensyvumo veloergometrinių krūvių metu buvo padidèjęs (Ratkevičius et al., 2006). Mūsų tyrimų, atliktų bègtakiu, duomenys rodo tik reikšmingą $\mathrm{VO}_{2}$ padidejjimą bėgant vidutiniu greičiu, nors matoma $\mathrm{VO}_{2}$ ir jo kaitos lètojo komponento padidejimo tendencija bėgant dideliu greičiu praejjus vienai valandai po prieškrūvio. Praejjus vienai parai po mūsų prieškrūvio reikšmingų pokyčių nebuvo, nors tiriamosios jautė vidutinišką raumenu skausmą ir sunkiau vertino atliekamą krūvị. Po ekscentrinių fizinių pratimų, sukèlusių raumenų pažaidą, bėgimo ekonomiškumas po vienos ir keturių paru buvo nepakitęs (Paschalis et al., 2005; Vassilis et al., 2008). $\mathrm{VO}_{2}$ bègant vidutiniu greičiu ir letasis $\mathrm{VO}_{2}$ komponentas bėgant dideliu greičiu padidejo praejjus vienai valandai po intervaliniu bėgimo pratybu (James, Doust, 1998; 1999). $\mathrm{VO}_{2}$ kinetinès ypatybès bėgant dideliu greičiu nepakito praèjus 4 minutėms po analogiško to paties intensyvumo prieškrūvio (Jones et al., 2008). Kita vertus, bègimo ekonomiškumas pablogejjo po 60 minučiu bėgimo dideliu intensyvumu (Sproule, 1998), taip pat šis rodiklis išliko tris dienas pablogejęs po 30 minučių bègimo nuokalne (Chen et al., 2007). Pastarojo tyrimo metu užfiksuotas panašaus dydžio $\mathrm{VO}_{2}$ prieaugis (4-7\%) kaip ir mūsų tyrimo metu (apie 5\% bėgant vidutiniu greičiu, tik mūsų atveju pokytis buvo pastebètas praejus vienai valandai po prieškrūvio).

Po 200 vertikalių didžiausių pastangų šuolių tiesiomis kojomis pasireiškia tokie blauzdos raumenu pažeidos požymiai kaip VRS ir sumažèjusi jèga (Finni et al., 2001; Twist et al., 2008). Mūsų tyrimo metu buvo atlikta 100 šuoliu (kiekvienas kas $20 \mathrm{~s}$ ) po nušokimų nuo $47 \mathrm{~cm}$ pakylos, todèl tiketina, kad buvo sukelta raumenu pažeida, nes tiriamosios praejjus 24 valandoms po prieškrūvio jautė vidutinišką blauzdos raumenų skausmą. Tikètina, kad toks protokolas galejo sumažinti blauzdos raumenu jèga, kadangi po panašaus protokolo, tik atliekant šuolius po nušokimų pusiau pritūpus, šlaunies raumenu jèga išliko sumažejusi bent jau 24 valandas (Skurvydas et al., 2000). Ko gero, pažeidos dydis buvo per mažas, kad paveiktų bè- gimo ekonomiškumą praejjus parai po prieškrūvio. Kita vertus, blauzdos raumenu masè nèra tokia didelè, kad labai pastebimai paveiktų organizmo deguonies suvartojimo greiti. Keletas veiksniu gali paveikti bėgimo ekonomiškumą: raumenų temperatūra, kvėpavimo koeficiento dydis, plazmos katecholaminų koncentracija, raumenu glikogeno atsargos, raumenu pažeida (Calbet et al., 2001). Manoma, kad bègimo ekonomiškumo pokyčiai gali būti susiję su didesniu II tipo (greitujų) raumenu skaidulų rekrutavimu (Calbet et al., 2001). Galima manyti, kad bėgant po prieškrūvio dèl nuovargio ir raumenų skaidulų jègos sumažejimo buvo rekrutuojama daugiau greitujų raumenų skaidulų, kuriu darbo veiksmingumas yra blogesnis (Nakagawa et al., 2005). Tai galejo padidinti deguonies sąnaudas mūsų tiriamujų atliktų krūvių atveju. Sunku paaiškinti, kodèl didesnis poveikis buvo pastebimas bėgant mažesniu greičiu, nors panaši tendencija išliko ir bėgant didesniu greičiu, tik pokytis nesieke statistiškai reikšmingo lygmens. Dèl sumažejjusios raumenu jègos galèjo pasikeisti bejgimo kinematiniai ypatumai ir paveikti bėgimo ekonomiškuma (Braun, Dutto, 2003). Blogesnis ištempimo ir susitraukimo ciklo panaudojimas bègant taip pat gali būti bègimo ekonomiškumo pablogejjimo priežastis. Nustatyta, kad toks gebejimas pablogejja po šuoliu (Byrne, Eston, 2002). Raumenu glikogeno atsargu sumažèjimas taip pat gali būti susijęs su bėgimo ekonomiškumo pablogejjimu (Kirwan et al., 1988), tačiau tai vargu ar galèjo turèti didelès reikšmès atliekant mūsų tyrimą, nes atlikto krūvio apimtis buvo nedidelè, nušokimai ir šuoliai buvo atliekami kas 20 sekundžių, todèl tikètinas nedidelis ATP resintezès iš angliavandenių indèlis atliekant toki krūvị. Kraujo laktato koncentracija ir kvėpavimo koeficientas reikšmingai nekito abiem krūvių atvejais, todèl raumenų energijos pokyčiai negalèjo paveikti deguonies suvartojimo.

\section{IŠVADA}

Ekscentrinis-koncentrinis blauzdos raumenu prieškrūvis (100 šuoliukų, atliekamų tiesiomis kojomis po nušokimo nuo $47 \mathrm{~cm}$ pakylos) praejus vienai valandai po jo padidina deguonies suvartojimą pastovios būklès fazèje bègant vidutiniu greičiu. Neturi reikšmingo poveikio ir šio rodiklio dydžiui praejjus 24 valandoms po prieškrūvio, taip pat deguonies suvartojimo dydžiui bei jo kaitos greičiui bėgant dideliu greičiu, šio rodiklio kaitos greičiui bègant vidutiniu ir dideliu greičiu praejjus vienai ir 24 valandoms po prieškrūvio. 


\section{LITERATŪRA}

Armstrong, R. B. (1984). Mechanisms of exercise-induced muscle soreness: A brief review. Medicine and Science in Sports and Exercise, 16, 529-538.

Braun, W. A., Dutto, D. J. (2003). The effects of a single bout of downhill running and ensuing delayed onset of muscle soreness on running economy performed $48 \mathrm{~h}$ later. European Journal of Applied Physiology, 90 (1-2), $29-33$.

Byrne, C., Eston, R. (2002). The effect of exercise induced muscle damage on isometric and dynamic knee extensor strength and vertical jump performance. Journal of Sports Sciences, 20 (5), 417-425.

Calbet, J. A., Chavarren, J., Dorado, C. (2001). Running economy and delayed onset muscle soreness. The Journal of Sports Medicine and Physical Fitness, 41 (1), 18-26. Chen, T. C., Nosaka, K., Tu, J. H. (2007). Changes in running economy following downhill running. Journal of Sports Sciences, 1, 25 (1), 55-63.

Davies, C. T, White, M. J. (1998). Muscle weakness following eccentric work in man. Pflügers Archives: European Journal of Physiology, 392 (2), 168-171.

Davies, C. T. M., White, M. J. (1981). Muscle weakness following eccentric work in man. Pflügers Archives: European Journal of Physiology, 393, 168-171.

Davis, H. A., Gass, G. C. (1981). The anaerobic threshold as determined before and during lactic acidosis. European Journal of Applied Physiology, 47, 141-149.

Endo, M., Usui, S., Fukuoka, Y. et al. (2004). Effects of priming exercise intensity on the dynamic linearity of the pulmonary $\mathrm{VO}_{2}$ response during heavy exercise. European Journal of Applied Physiology, 91, 545-554.

Finni, T., Ikegawa, S., Komi, P. V. (2001). Concentric force enhancement during human movement. Acta Physiologica Scandinavica, 173 (4), 369-377.

Friden, J., Sfakianos, P. N., Hargens, A. R., Akeson, W. H. (1986). Muscles soreness and intramuscular fluid pressure: Comparison between eccentric and concentric load. Journal of Applied Physiology, 61, 2175-2179.

Friden, J., Sfakianos P. N., Hargens, A. R., Akeson, W. H (1988). Residual muscle swelling after repetitive eccentric contraction. Journal of Orthopaedic Research. Official Publication of the Orthopaedic Research Society, 6, 49-498.

Friden, J., Sjostrom, M., Ekblom, B. (1983). Myofibrillar damage following intense eccentric exercise in man. International Journal of Sports Medicine, 4, 170-176.

James, D. V., Doust, J. H., (1999). Oxygen uptake during high - intensity running: Response following a single bout of interval training. European Journal of Applied Physiology and Occupational Physiology, 79 (3), 237- 243.

James, D. V., Doust, J. H. (1998). Oxygen uptake during moderate intensity running: Response following a single bout of interval training. European Journal of Applied Physiology and Occupational Physiology, 77 (6), 551555
Jones, A. M., DiMenna, F., Lothian, F. et al. (2008). "Priming" exercise and $\mathrm{O}_{2}$ uptake kinetics during treadmill running. Respiratory Physiology \& Neurobiology, 30161 (2), 182- 188 .

Kirwan, J. P., Costill, D. L., Mitchell, J. B. et al. (1998). Carbohydrate balance in competitive runners during successive days of intense training. Journal of Applied Physiology, 65 (6), 2601- 2606.

Nakagawa, Y., Ratkevicius, A., Mizuno, M., Quistorff, B. (2005) ATP economy of force maintenance in human tibialis anterior muscle. Medicine and Science in Sports and Exercise, 37, 937-943.

Paschalis, V., Koutedakis, Y., Baltzopoulos, V. et al. (2005). The effects of muscle damage on running economy in healthy males. International Journal of Sports Medicine, 26 (10), 827-831.

Ratkevičius, A., Stasiulis, A., Dubininkaite, L., Skurvydas, A. (2006). Muscle fatique increases metabolic costs of ergometer cycling without changing $\mathrm{VO}_{2}$ slow component. Journal of Sports Sciences and Medicine, 5, 440-448.

Sanchis Moysi, J., Garcia-Romero, J. C., Alvero-Cruz, J. R. et al. (2005). Effects of eccentric exercise on cycling efficiency. Canadian Journal of Applied Physiology, 30 (3), $259-275$.

Sargeant, A. J., Dolan, P. (1989). Human muscle function following prolonged eccentric exercise.. European Journal of Applied Physiology, 56, 704-711.

Schneider, D. A., Berwick, J. P., Sabapathy S., Minahan C. L. (2007). Delayed onset muscle soreness does not alter $\mathrm{O}_{2}$ uptake kinetics during heavy - intensity cycling in humans. International Journal of Sports Medicine, 28 (7), 550-556

Skurvydas, A., Jascaninas, J., Zachovajevas, P. (2000). Changes in height of jump, maximal voluntary contraction force and low-frequency fatigue after 100 intermittent or continous jumps with maximal intensity. Acta Physiologica Scandinavica, 169, 55-62.

Sproule, J. (1998). Running economy deteriorates following 60 min of exercise at $80 \% \mathrm{VO}_{2}$ max. European Journal of Applied Physiology, 77 (4),366-371.

Tordi, N., Perrey, S., Harvey, A., Hughson, R. L. (2003). Oxygen uptake kinetics during two bouts of heavy cycle separated by fatiguing sprint exercise in humans. The Journal of Applied Physiology, 94, 533-541.

Twist, C., Gleeson, N., Eston, R. (2008). The effects of plyometric exercise on unilateral balance performance. Journal of Sports Sciences, 26 (10),1073-1080.

Vassilis, P., Vassilios, B., Vassilis, M. et al. (2008). Isokinetic eccentric exercise of quadriceps femoris does not affect running economy. Journal of Strength and Conditioning Research, 22 (4), 1222-1227.

Whipp, B. J., Ward, S. A., Lamarra, N., Davis, J. A., Wasserman, K. (1982). Parameters of ventilatory and gas exchange dynamics during exercise. Journal of Applied Physiology, 52 (6), 1506-1513. 


\title{
THE EFFECT OF PRECEDING DROP JUMPS ON VO KINETICS DURING MODERATE AND HEAVY INTENSITY RUNNING IN YOUNG WOMEN
}

\author{
Kristina Zaičenkovienė, Arvydas Stasiulis \\ Lithuanian Academy of Physical Education, Kaunas, Lithuania
}

\begin{abstract}
The aim of the study was to determine the effect of preceding 100 jumps performed with stretched legs after dropping from $47 \mathrm{~cm}$ height on the oxygen uptake kinetics while running at moderate and heavy intensities. Nine physically active women participated in this study. Their age, height, weight and VO2max were $22.8(4,1)$ ears, $1.65(0,48) \mathrm{m}, 58.1(4,7) \mathrm{kg}$ and $42,4(6,0) \mathrm{ml} / \mathrm{kg} / \mathrm{min}$, respectively. On different days the subjects performed four running exercises on the treadmill. The pulmonary gas exchange data, heart rate, rates of perceived exertion, blood lactate were recorded while performing all the exercises. During the first visit the increasing running exercise was performed for the determination of $\mathrm{VO}_{2}$ max and ventilatory thresholds (VT). During the following three visits the subjects performed two constant speed running activities at moderate ( $90 \%$ from the first VT) and heavy intensities (first VT + the $75 \%$ of difference between VT). Several days after control running the constant load exercises were preceded by 100 jumps, performed every $20 \mathrm{~s}$ with stretched legs after dropping from $47 \mathrm{~cm}$ height (PJ). The constant speed running was then repeated $1 \mathrm{~h}$ and $24 \mathrm{~h}$ after PJ.

The results showed that significant changes of oxygen uptake parameters were observed during moderate intensity running performed $1 \mathrm{~h}$ after PJ: the amplitude of fast phase of $\mathrm{VO}_{2}$ response and the means of $\mathrm{VO}_{2}$ at 4-th, 5-th and 6-th min of exercise were increased. $24 \mathrm{~h}$ after JPG as well as in both cases during heavy intensity running no significant changes were observed. In addition, the rates of perceived exertion were significantly increased during moderate intensity running $24 \mathrm{~h}$ following PJ.

In conclusion eccentric concentric preceding exercise of calf muscles (100 drop jumps with stretched legs) causes an increase in oxygen uptake during the phase of steady state phase of running at moderate intensity performed $1 \mathrm{~h}$ after PJ without significant effect on oxygen uptake kinetics. Both parameters of oxygen uptake are not affected by PJ during heavy intensity running.
\end{abstract}

Keywords: oxygen uptake, perceived exertion, prior exercise, constant load, running.

Gauta 2010 vasario 4 d.

Received on February 4

Kristina Zaičenkovienè

Lietuvos kūno kultūros akademija

(Lithuanian Academy of Physical Education)

Sporto g. 6, LT-44221 Kaunas

Lietuva (Lithuania)

Tel +37061620238

Email zaicenkoviene@yahoo.co.uk 